\title{
BREXIT OPTIONS FROM THE PERSPECTIVE OF ECONOMIC INTEGRATION STAGES
}

\author{
DOI: 10.17261/Pressacademia.2019.1016 \\ JBEF- V.8-ISS.1-2019(6)-p.71-81
}

\section{Ozlem Toplu Yilmaz}

Istanbul Yeni Yuzyil University, Istanbul, Turkey. ozlem.yilmaz@yeniyuzyil.edu.tr, ORCID: 0000-0001-5335-8370

To cite this document

Yilmaz, O. T. (2019). Brexit options from the perspective of economic integration stages. Journal of Business, Economics and Finance (JBEF), V.8(1), p.71-81.

Permemant link to this document: http://doi.org/10.17261/Pressacademia.2019.1016

Copyright: Published by PressAcademia and limited licenced re-use rights only.

\begin{abstract}
Purpose - This research examines the exit options of the United Kingdom from the European Union and discusses the possible trade relations between the United Kingdom and the European Union after the exit.

Methodology - In this article, the exit options are discussed from the perspective of the economic integration stages. The monetary union stage is evaluated by using least squares method.

Findings - The monetary union would not lead to significant changes in the import and export levels of the United Kingdom. Customs Union is the first best for the United Kingdom as she will have closer trade relations with the European Union, and on the other side, will pursue its own dependent trade policies against the other countries.

Conclusion - From the perspective of economic integration stages, the first best would be the Customs Union. If both sides do not agree on the Customs Union, then the second best will be free trade area, in that the UK and the EU can make trade agreements that cover crucial trade products for both sides.
\end{abstract}

Keywords: Brexit, single market, economic integration, European Union, customs union. JEL Codes: F150, F36, F020

\section{INTRODUCTION}

Britain became a member of the European Union in 1973. After its membership, Britain's problems like the budgetary spending and the single currency started. In 1975, two years after Britain's membership, a referendum was held for remaining in the Union or not, and the British people voted for staying in the Union. The second referendum for Britain's EU membership was held in 2016. This time the referendum result was "exit" from the European Union. Britain notified the European Council of its intention to leave the European Union on March, 29, 2017, and the exit negotiations started. Britain will exit from the Union in March 2019.

Britain is in the single market stage and did not enter the Monetary Union. Some options were argued for the Brexit. The first option was hard exit which foresees an access to the customs union, and the second option is soft Brexit that ensures the access to the single market. The period of exit negotiations was named as Brexit. Brexit is the short expression of Britain's leaving the Union, formed by merging the words Britain and exit. This study aims to analyse Brexit options from the perspective of the economic integration stages; from the loosest stage to the deepest stage like free trade area, customs union, the single market, and monetary union. Possible trade relations between the United Kingdom and the EU after the exit will be discussed. European Union's close economic relations with some of the non-member countries are examined in order to consider the options for 
future European Union-Britain trade relations. The constraint of the study is that the free movement of capital and people is not mentioned. The free movement of people was one of the reasons for leaving the European Union because of the immigration and the unemployment benefit that the immigrants receive. The impact of the immigration on the United Kingdom's labour market and the burden of the immigrants on the United Kingdom's economy were not taken into account. This study covers only the free movement of goods, in other words, the trade relations between the UK and the European Union were analysed.

\section{LITERATURE REVIEW}

Simon Bulmer and Lucia Quaglia (2018) analysed the background of Brexit and discussed the dynamics of the Brexit negotiations in their article. They explained the phases of the negotiations. According to the authors, the United Kingdom's (UK) departure may remove one semi-detached member from the EU but Brexit is but one of several challenges to EU governance and integration that will be under scrutiny from EU scholars over the coming months and years. Thomas Sampson (2017) assessed the options after Brexit and found out that in the long-run Brexit will make the United Kingdom poorer because it will create new borders to trade, foreign direct investment, and immigration. European Union countries are also likely to suffer from reduced trade. John Van Reenen (2016) analysed the long-run economic effects of the United Kingdom's decision to leave the European Union from the perspective of the trade, foreign direct investment, immigration, and regulations. In his article, according to the author Brexit's supposed benefits-such as lower immigration, better regulations, and more trade deals with non-EU countries - would have little effect little or nothing to offset welfare losses like lower trade and foreign investment and lower UK incomes. If there is a "hard Brexit," trade costs will arise from tariff and nontariff barriers. For example, Akses et al. (2016) analysed the exit process of Britain and its impact on political, economic and trade, and examined the impacts of Brexit on the future Turkey-EU relations in their report. According to the authors, Brexit may lead to the disintegration of the European Union and affect the cornerstones like the common currency and the free movement in the Union negatively.

Begg (2016) studied the economics of Brexit and examined why the referendum resulted in the vote to leave and explores what the ramifications are for both Britain and the future of the European Union. The author stated that the Eurozone requires increased integration in order to function effectively. Soytürk (2017) analysed the role of the United Kingdom inside the European Union and examined the political reasons of the referendum, and pointed out the political and economic results of it that will occur in the near future. According to the author, an exit of a big country from the Union means losing the dominance of the European Union. The author stated that the outcomes of the exit will not be satisfactory for both sides. Efe (2017) examined the exit options with references to Norwegian, Swiss and EFTA models by explaining their advantages and disadvantages. The author considers that Britain will continue to be in the Union, but its membership will not lead to a significant problem for security in the European Continent. Konuralp, Adaş (2018) analysed the historical background of this milestone and its causes and they assessed the models regulating the relations between non-member states, in order to discuss a suitable model for the UK in the post-Brexit era. According to the authors, none of the models (Norway, Switzerland, Canada, Customs Union, and WTO) would solve the problems of the UK and emphasized the Brexit process would negatively affect the UK and other EU members in economic and political terms. To sum up, the most of the authors conclude that Brexit will not be a best solution for both sides, because Britain and the European Union will be affected negatively from the exit process. The costs of the exit will arise in Britain as Britain will not benefit from some common policies of the EU. On the other hand, Britain's exit may hit the integration process of the Union.

\section{DATA AND METHODOLOGY}

This study covers the United Kingdom's problems in the European Union regarding the Common Budget and the Monetary Union, and the Brexit options. These problems are crucial to assess the Brexit options from the perspective of economic integration stages. The European Union's economic relations with some of the non-member countries in the Europe are analysed and the exit options for Britain are assessed through the trade statistics. The monetary union stage is evaluated by using least squares method.

\subsection{Britain's Problems in the EU regarding the Common Budget and the Monetary Union}

The United Kingdom ${ }^{1}$ became a member of the European Union sixteen years after its foundation. European Union was created by six countries in 1957 as the European Economic Community (EEC). After its foundation, the EEC Customs Union was formed in three stages of four years each. The first stage began in 1958 and the intra-EEC tariffs were eliminated from 1969 onwards.

\footnotetext{
${ }^{1}$ The United Kingdom and Britain are used interchangeably in this study. However, in fact, the full name of the country is "United Kingdom of Great Britain and Northern Ireland".
} 
Common External Tariff was applied by the EEC members. Thus, the EEC became a large market for the firms. During the formation of the Customs Union, the EEC's share in its own trade rose from about $30 \%$ to almost $50 \%$ (Baldwin and Wyplosz, 2006: 14). The EEC integration diminished the relative competitiveness of non-EEC firms in EEC markets, thereby harming their sales and profits (Baldwin and Wyplosz, 2006: 14). Also, UK industries faced rising discrimination in Europe's growing largest markets (Baldwin and Wyplosz, 2006: 15). For especially economic reasons, United Kingdom decided to apply for EEC membership.

The United Kingdom first applied for EEC membership in 1961 and de Gaulle vetoed the British application stating that the United Kingdom had close relationships with the United States of America. Also, de Gaulle saw the EEC as a counterbalance to American power and did not want British membership undermining this (Lynch, 2012: 64). Another reason for De Gaulle's veto was that, De Gaulle was suspicious for Great Britain to accept a common tariff, for this would involve giving up all Commonwealth preferences (Lynch, 2012: 63). In 1967, the United Kingdom again applied for EEC membership, and De Gaulle rejected the British application second time because of the same reasons, especially because of the ties with the Commonwealth countries and also because of the relations between the United States and the United Kingdom. After De Gaulle's resignation in 1969, the United Kingdom could join the EEC in 1973. EEC membership decision was taken by Edward Heath's government. ${ }^{2}$

Britain had never carried out close economic cooperation with the Community during her membership. Britain's problems with the European Union from the economic side during her membership can be summarised as UK rebate which was about Common Agricultural Policy (CAP) spending and also about being in the monetary union or not. Firstly, she faced with the CAP spending problems in the Community after she joined the EEC. The main problem was that agricultural spending was dominating the budget. Farm spending after the establishment of CAP took $80 \%$ or more of the total expenditure making up 92\% of the budget in 1970 (Baldwin and Wyplosz, 2006: 59). However, Britain's agricultural sector was small: agricultural share in GDP was $4.3 \%$ in 1969. (Redhill Academy: 6).

The UK rebate regarding the CAP spending problem dated back to 1980s. According to the Luxembourg Treaty in 1970, the European Council decided for the introduction of "own resources" system. This system included the financing of the CAP through agricultural levies, customs duties, and VAT (value-added tax) resources. Agricultural levies were import taxes charged from agricultural goods from the third countries. The UK also imported a larger share of its food from non-member nations and import taxes charged on such imports were turned over to the EU budget (Baldwin and Wyplosz, 2006: 63). There was an imbalance between the UK's contribution to the EU budget and the UK's receiving from the share of the EU funding. Shortly, Britain was the net contributor to the budget. At Fontainebleau summit in 1984, Prime Minister Margaret Thatcher demanded excess contribution of UK. The UK rebate implemented in 1985 to correct the imbalance between UK's contribution to the CAP and benefits from the CAP. The EU leaders decided to give the EU two-thirds of its net contribution (Baldwin and Wyplosz, 2006: 63). Each year, the amount of the rebate is determined by a complex calculation, linked to several variables and which has evolved over time to take into account developments in the EU and its financing system (European Parliament, 2016).

Secondly, the UK also decided to stay out of the Euro-area. A single currency plan dated back to 1970 s. Werner Plan in 1970 proposed a monetary union which would be established in ten years and a "Snake arrangement" was created. Under this mechanism, Member States' currencies could fluctuate (like a snake) within narrow limits against the dollar (the tunnel) and central banks could buy and sell European currencies, provided that they remained within the fluctuation margin of $2.25 \%$ (European Parliament, 2015: 3). The participants of the system were Germany, Denmark, Netherlands, France, Luxembourg, Italy, Norway and the United Kingdom. But the mechanism collapsed because of the member countries' different reactions to the oil shock in 1973. Sterling, the Italian lira and the French franc chose to float separately on their own, Benelux countries, Denmark and some non-EC countries linked with Germany made no progress allowing a divergence of inflation rates (Robson, 1998: 219). The new European Monetary System was established in 1979 and the European Currency Unit (ECU) was the basic element of the system which set an exchange rate towards the ECU for each participating currency (European Parliament, 2015: 3). In 1988, Delors Report proposed that economic and monetary union should be achieved in three stages (European Central Bank): Stage 1 started in 1990 which proposed complete freedom of capital transactions, increased co-operation between central banks, free use of the ECU and improvement of economic convergence. Second stage started in 1994, proposing the establishment of the European Monetary Institute and strengthening of economic convergence. Stage 3 started in 1999 and Euro was introduced.

${ }^{2}$ Edward Heath became Conservative Party leader more than 50 years ago and served as UK prime minister between 1970 and 1974. (BBC, 2017, October 04). 
The UK joined the ERM in 1990. With inflation of $10 \%$ in UK in the 1980s, Nigel Lawson was able to convince Mrs. Thatcher that the UK would benefit from joining the ERM to help reduce the inflation (Pettinger, 2016). High inflation and deteriorating economic activity were making the Pound less attractive. Therefore, the Pound kept falling to its lower limit in the ERM. Therefore, the government was bound to protect this value of the Pound by increasing interest rates. The UK government increased the interest rates to $15 \%$. The high-interest rates should attract hot money flows. But the market knew these interest rates were unsustainable and couldn't be maintained; the selloff continued and eventually, the government left the ERM. The Pound fell 15\%, interest rates were cut, and the economy was able to recover (Pettinger, 2016). After leaving the ERM in 1992, the UK economy recovered. This was due to devaluation, but also interest rates were able to fall significantly (Pettinger, 2016).

Maastricht Treaty was signed in 1991, setting out the criteria and the stages to establish the European Monetary Union. The main objective was price stability. The first country to sign the Treaty was Denmark. But Danes voted against the Treaty. After that speculative attacks started initially targeting Italy (the lira was seriously overvalued by then) and the UK (Baldwin and Wyplosz, 2006: 338). UK and Italy had to leave the ERM (later, Italy turned to the ERM). Currencies of Ireland, Spain and Portugal were devalued.

The Cannes European Council in June 1995 confirmed that the year 1999 would be the starting date for the Economic and Monetary Union and European leaders at the Madrid European Council in December decided to name the new European currency the 'euro' (European Parliament, 2015 March: 4). This mechanism was called 'ERM II'. Protocol (No 25) on certain provisions relating to the United Kingdom of Great Britain and Northern Ireland (1992) specified the provisions of the United Kingdom's opt-out from moving to the third stage of economic and monetary union (European Union, 2006, June 30). United Kingdom did not introduce the euro and is still in the second stage of EMU. The opt-out clause was a condition for the United Kingdom to approve the Treaty as a whole (European Union, 2006, June 30).

\subsection{Britain's Intention for Exit}

In 1975, two years after Britain joined the EU, Britain held a referendum under Harold Wilson's Labour government. 67\% of people voted to remain in the Union and Britain stayed in the Union (The Telegraph, 2016).

On 23 June 2016, a referendum was held about the UK's future in the European Union whether to leave or remain in the Union. Votes for leaving was $51.9 \%$ and votes for remain was $48.1 \%$ (The Electoral Commission). So, the United Kingdom voted to leave the European Union. There were some reasons for the citizens who vote for leaving. One important reason was UK's contribution to the budget in large amounts but for little in return. Free movement and immigration were the other exit reasons for the British people (Hunt and Wheeler, 2018).

On March 29, 2017, the UK officially notified the European Council of its intention to leave the EU under Article 50 of the Lisbon Treaty. This Article explains the procedures for exit from the Union. The member state does not have to state a reason for leaving. According to Article 50 of the Lisbon Treaty, a member state may decide to withdraw from the Union in accordance with its own constitutional requirements and shall notify the European Council of its intention. That agreement will be negotiated in accordance with Article 218(3) of the of the Treaty on the Functioning of the European Union.

Brexit negotiations started on June 19, 2017. The exit negotiations will shape the future relations with the Union and the UK. According to the Lisbon Treaty, the Union and the United Kingdom will have two years after notification for the deal and both sides can decide to extend this period.

\subsection{Brexit Options}

This study will examine Brexit options and also will look at the monetary union stage which was never argued during the UK's membership.

The United Kingdom's EU membership did not go further beyond the single market (common market) stage in the European Union. ${ }^{3}$ Therefore, UK will, in fact, exit from the common market. Common market is an economic integration model which allows free movement of labour and capital among the member countries and also includes the customs union conditions like application of common external tariff to non-member nations but no tariffs and other trade barriers among member nations.

\footnotetext{
${ }^{3}$ The European Union has been a successful economic integration model since its foundation. European Union has transformed from customs union into an economic union in time. Firstly, EU formed the customs union in 1968. European Union became a common market at the beginning of 1993. Monetary Union established in 1999 with the introduction of Euro. European Union achieved the status of the economic union also at the end of 1990 s with the establishment of supranational organisations like the European Central Bank.
} 
The future economic relationship between the UK and the EU is not precise yet, but the European Union's close economic relations with some of the non-member countries in the Europe can be helpful to shape the future trade relations. Table 1 summarises the connections of the non-member states which had close economic relations with the European Union.

Table 1: European Union's Economic Relation Models with Some Non-Member Countries

\begin{tabular}{|l|l|l|l|l|l|l|}
\hline & Norway & Switzerland & Turkey & Ukraine & Liechtenstein & Iceland \\
\hline Customs tariffs & No & No & $\begin{array}{l}\text { No tariffs on } \\
\text { industrial goods } \\
\text { agricultural } \\
\text { goods and some } \\
\text { industrial goods }\end{array}$ & No & No \\
\hline Free Trade Agreement & No & No & No & Yes & No & No \\
\hline Customs Union & No & No & Yes & No & No & No \\
\hline Single market & Yes & Partial & No & No & Yes & $\begin{array}{l}\text { Highly } \\
\text { integrated }\end{array}$ \\
\hline Budgetary contribution & Yes & Yes & No & No & Yes & Yes \\
\hline
\end{tabular}

Source: Author

Norway has full access to the single market, being a member of European Economic Area (EEA) ${ }^{4}$. Agriculture and fisheries are not covered by the EEA Agreement. Norway has also its dependent trade policy. Norway does not apply tariffs to the EU imports and vice versa. Also, Norway makes a budgetary contribution to the EU.

Switzerland has a partial access to the EU's single market for services. There is free movement of people between Switzerland and the EU. Switzerland has an independent trade policy. Switzerland's economic and trade relations with the EU are mainly governed through a series of bilateral agreements (European Commission, 2018a). Tariffs on Swiss manufactures are generally low, and in principle, there are no quantitative restrictions, anti-dumping, countervailing or safeguard actions. There are however significant tariffs on a number of agricultural products such as meat or on certain processed agricultural products (European Commission, 2018a). Switzerland pays a financial contribution to economic and social cohesion in the new EU Member States.

Turkey is a candidate country for EU membership. Turkey-EU trade relation is based on Customs Union. Customs Union between EU and Turkey which entered into force on January 01, 1996, comprised of free movement of industrial goods and processed agricultural goods. Turkey has no access to the single market. Customs Union is a looser economic integration model when compared to the single market. Also, Turkey does not make any budgetary contribution to the European Commission.

The EU and Ukraine have applied their Deep and Comprehensive Free Trade Agreement (DCFTA) since 1 January 2016. This agreement ensures free access to their markets for goods and services for both sides based on predictable and enforceable trade rules (European Commission, 2018a).

The EU and the Principality of Liechtenstein are close economic and political partners in the context of the EEA, which Liechtenstein joined in 1995 (European Union External Action, 2016, September 26). Liechtenstein also makes a budgetary contribution to the Commission.

Iceland is also highly integrated to the single market and makes a budgetary contribution to the Commission.

The possible relationship between United Kingdom and the European Union after Brexit period is a discussion subject. These European Union's economic models with non-member countries can give foresight about the future UK's position in the EU. Some options are argued about the future position of the United Kingdom in Europe. The Brexit model will depend on the future closeness of United Kingdom to the Union.

${ }^{4}$ The European Economic Area (EEA) brings together the EU Member States and three of the EFTA States (Iceland, Liechtenstein and Norway). It was established by the EEA Agreement, an international agreement which enables these three EFTA States to participate fully in the Single Market. It covers the four freedoms, i.e. the free movement of goods, capital, services and persons, The EEA Agreement does not cover the following EU policies: common agriculture and fisheries policies (although the EEA Agreement contains provisions on trade in agricultural and fish products); customs union; common trade policy; common foreign and security policy; justice and home affairs (the EEA EFTA States are however part of the Schengen area); direct and indirect taxation; or economic and monetary union. (Source: EFTA. Retrieved from http://www.efta.int/eea/eea-agreement/eea-basic-features). 
Table 2: Stages of Economic Integration/Non-Member Countries

\begin{tabular}{|l|l|l|l|l|}
\hline $\begin{array}{l}\text { Stages of Economic } \\
\text { Integration/Member and } \\
\text { Non-member countries }\end{array}$ & Free Trade Area & Customs Union & Single Market & Monetary Union \\
\hline & Ukraine & Turkey & $\begin{array}{l}\text { Norway } \\
\text { Liechtenstein } \\
\text { Iceland (partly) } \\
\text { Switzerland (partly) }\end{array}$ & $\begin{array}{l}\text { Member countries } \\
\text { in the Euro-Area }\end{array}$ \\
\hline
\end{tabular}

Source: Author

\section{Free Trade Area}

Free trade area is the loosest form of economic integration. The option "hard exit" would exclude the United Kingdom from the single market which foresees no free movement of labour, capital and even goods. Later the two sides can make arrangements to settle economic and trade relations between each other after the exit. If UK does not participate in the single market or customs union, UK's imports will face with the tariff rates.

European Union is a big market for the EU members and also for non-EU members. Also, for the United Kingdom, EU is the largest trade destination. Animal products and chemicals have great shares in Britain's imports from the European Union accounting for $76 \%$ and $74 \%$ of its total imports, respectively (Table 3 ). UK has a negative trade balance against the other member states in all product groups except mineral fuels (Table 3). So, UK is a net importer in intra EU-trade. UK's negative trade balance has an increasing trend and recorded as the highest in 2016.

Table 3: Trade Balance of UK with the EU by Product Group, in million Euro (SITC category)

\begin{tabular}{|l|l|l|l|l|l|l|l|l|l|l|}
\hline Product Group & $\mathbf{2 0 0 7}$ & $\mathbf{2 0 0 8}$ & $\mathbf{2 0 0 9}$ & $\mathbf{2 0 1 0}$ & $\mathbf{2 0 1 1}$ & $\mathbf{2 0 1 2}$ & $\mathbf{2 0 1 3}$ & $\mathbf{2 0 1 4}$ & $\mathbf{2 0 1 5}$ & $\mathbf{2 0 1 6}$ \\
\hline $\begin{array}{l}\text { Food, drinks and } \\
\text { tobacco }\end{array}$ & -14.781 & -14.515 & -13.815 & -15.042 & -16.023 & -19.017 & -19.591 & -20.257 & -22.990 & -21.532 \\
\hline Raw materials & -2.734 & -2.160 & -1.893 & -1.677 & -1.548 & -1.615 & -2.711 & -3.635 & -4.218 & -4.291 \\
\hline $\begin{array}{l}\text { Mineral fuels, } \\
\text { lubricants and } \\
\text { related materials }\end{array}$ & 15.049 & 17.956 & 13.282 & 18.481 & 21.342 & 20.153 & 17.539 & 18.868 & 11.633 & 7.219 \\
\hline $\begin{array}{l}\text { Chemicals and } \\
\text { related products, } \\
\text { n.e.s. }\end{array}$ & -902 & -406 & -1.767 & -3.517 & -4.577 & -6.346 & -9.392 & -13.203 & -15.847 & -13.909 \\
\hline $\begin{array}{l}\text { Other } \\
\text { manufactured } \\
\text { goods }\end{array}$ & -13.359 & -13.312 & -15.003 & -16.649 & -20.656 & -19.120 & -21.542 & -24.132 & -23.778 & -24.44 \\
\hline $\begin{array}{l}\text { Machinery and } \\
\text { transport } \\
\text { equipment }\end{array}$ & -41.592 & -35.007 & -25.773 & -34.617 & -33.541 & -42.713 & -45.649 & -53.232 & -62.540 & -57.743 \\
\hline
\end{tabular}

Source: European Commission (2018b).

In the Union, Germany, Netherlands, Belgium, France, Italy, Spain, Sweden, Finland and Ireland are the biggest trade partners of Britain in the EU. Britain generally exports to Germany, France, Netherlands, and Ireland (Table 4). Britain's most of its export products from the European Union made up of footwear (87\%), animal products (74\%) and vegetables (73\%). UK mainly imports capital-intensive products from EU countries like chemicals, machinery, transport equipment, food and live products. 
Table 4: UK Trade in Goods, Top 5 Trading Partner Countries in 2016, Exports

\begin{tabular}{lll}
\hline Ranking & Country Description & Value fbn \\
\hline 1 & United States including Puerto Rico & 47,9 \\
2 & Germany & 32,3 \\
3 & France & 19,4 \\
4 & Netherlands & 19,0 \\
5 & Republic of Ireland & 16,8 \\
\hline Source: Office for National Statistics (2018, July 16)
\end{tabular}

Intra EU-trade made up of $44 \%$ of total EU trade, while $55 \%$ of UK's trade consists of extra EU trade (Eurostat, Comext table DS057009). Outside the EU, the United States and China are the biggest trade partners (Table 5).

Table 5: UK Trade in Goods, Top 5 Trading Partner Countries in 2016, Imports

\begin{tabular}{lll}
\hline Ranking & Country Description & Value fbn \\
\hline 1 & Germany & 63,4 \\
2 & China & 39,2 \\
3 & United States including Puerto Rico & 36,2 \\
4 & Netherlands & 35 \\
5 & France & 25 \\
\hline
\end{tabular}

Source: Office for National Statistics (2018, July 16).

\section{Customs Union}

Customs Union is being discussed as an exit option by the two sides. Customs Union can be a better option for the UK which would allow the UK to import duty-free goods from the EU and also to enter into its own trade agreements with other countries. But customs union covers only free movement of goods, not services. Customs Union can be a better option for Britain, as a free movement in services is not crucial for Britain. The US remains the single largest market for UK services exports, accounting for $£ 8,570$ million, or $22.7 \%$ of all UK exports (Table 6,7 ). Britain can replace the trade in services from the EU by trade in services from the US:

Table 6: Ten Largest UK Quarterly Trade in Services Import Partner Countries, Quarter 1 (Jan to Mar) 2017 to Quarter 12018 , Sterling

\begin{tabular}{llllll} 
& Q1 & Q2 & Q3 & Q4 & Q1 \\
& $\mathbf{2 0 1 7}$ & $\mathbf{2 0 1 7}$ & $\mathbf{2 0 1 7}$ & $\mathbf{2 0 1 7}$ & $\mathbf{2 0 1 8}$ \\
\hline United States & 4.364 & 4.899 & 4.586 & 4.662 & 4.212 \\
Germany & 1.441 & 1.404 & 1.649 & 1.527 & 1.488 \\
France & 1.196 & 1.106 & 1.272 & 1.261 & 1.182 \\
Ireland & 1.053 & 1.170 & 1.390 & 1.261 & 1.112 \\
Netherlands & 915 & 927 & 955 & 1.246 & 974 \\
Japan & 892 & 794 & 897 & 921 & 862 \\
India & 601 & 600 & 535 & 572 & 753 \\
Sweden & 341 & 558 & 600 & 431 & 681 \\
Switzerland & 650 & 630 & 700 & 727 & 592 \\
Luxembourg & 590 & 610 & 593 & 677 & 525 \\
Rest of World & 6.507 & 6.405 & 7.181 & 7.038 & 6.527 \\
\hline
\end{tabular}

Source: Office for National Statistics (2018, July 16). 
Table 7: Ten Largest UK Quarterly Trade in Services Export Partner Countries, Quarter 1 (Jan to Mar) 2017 to Quarter 12018 , Sterling

\begin{tabular}{llllll} 
& Q1 & Q2 & Q3 & Q4 & Q1 \\
& $\mathbf{2 0 1 7}$ & $\mathbf{2 0 1 7}$ & $\mathbf{2 0 1 7}$ & $\mathbf{2 0 1 7}$ & $\mathbf{2 0 1 8}$ \\
\hline United States & 8.040 & 8.164 & 8.489 & 9.392 & 8.570 \\
Germany & 2.552 & 2.507 & 2.742 & 2.841 & 2.449 \\
Ireland & 2.203 & 2.274 & 2.718 & 3.414 & 2.344 \\
Netherlands & 1.994 & 2.462 & 2.698 & 2.775 & 2.338 \\
Switzerland & 2.065 & 1.906 & 1.978 & 2.449 & 2.056 \\
France & 1.708 & 1.807 & 1.865 & 2.084 & 1.827 \\
Luxembourg & 832 & 733 & 819 & 972 & 945 \\
Saudi Arabia & 1.334 & 1.524 & 1.149 & 1.236 & 829 \\
Japan & 759 & 880 & 848 & 832 & 781 \\
Spain & 725 & 798 & 837 & 753 & 725 \\
Rest of World & 14.658 & 16.384 & 15.175 & 18.830 & 14.907 \\
\hline Source: Office for National Statistics $(2018$, July 16$)$ & & &
\end{tabular}

Source: Office for National Statistics (2018, July 16)

\section{Single Market}

As mentioned before, some possible scenarios for the Brexit come into question. One option is soft Brexit which involves the closest relationship between the two sides. In the case of a soft exit, United Kingdom would be in the single market. It means the free access to the EU's market. However, the UK would no longer be a member of the EU and would not have a seat on the European Council. It would lose its MEPs and its European Commissioner (Sims, 2016, October 03).

The crucial advantage of being in a single market is lower intra-EU trade costs. According to Reenen (2016: 371); in the optimistic soft Brexit scenario, in the 10 years following Brexit, intra-EU trade costs will fall 20 percent faster than in the rest of the world; while in the hard Brexit scenario, intra-EU trade costs will fall 40 percent faster. So, UK would not benefit from reduced costs, on the contrary, would face with tariff and non-tariff barrier costs.

\section{Monetary Union}

According to the Optimum Currency Area model of Mundell, a single currency, in other words, a monetary union can stimulate trade between member countries because the trade will not be harmed by exchange rate volatilities. The United Kingdom did not participate in the Monetary Union. Since the Sterling is international reserve money and a strong currency, it is thought that the changes in the exchange rate will be reflected in the trade data. The rise in the Euro/Sterling exchange rate (depreciation of Sterling) can lead to a decrease in the import from the EU and to the increase in the export to the EU.

In order to examine whether exchange rate affects the trade between EU and the UK, import and export models are estimated for the United Kingdom by using the least squares method.

Ho: There is a negative correlation between Euro/Sterling rate and UK's import from the Union

\section{$\mathrm{H} 1$ : There is no relation between the variables}

The data are times series and represent 45 years, from 1973 to 2017 and collected from the Eurostat, the Statistical Office of the European Union. For estimating the UK's import model, UK's GDP, UK's population and euro/sterling rate are selected as explanatory variables. These variables are important for examination for a country's import data. For estimating the UK's export model, variables like Euro/Sterling rate, GDP of the EU, population of EU are added in the model.

Estimated models are tested for normality, heterosceadasticity, specification error and structural breakpoint by using Durbin Watson d, Durbin h, Jarque bera, Heterosceadasticity White, Ramsey Reset and Cusum Square (CUSUMSQ) tests. The coefficients of the estimated parameters in the regression models are found significant. R-Squared is close to 1 , this shows a good fit of the model. At the $5 \%$ significance level, Prob(F-statistic) is significant. Specification of the estimated model is checked by CUSUM test. The CUSUM statistic is plotted with $5 \%$ significance confidence bounds in the import model. However, there is structural breakpoint after 2013 as seen in the CUSUMSQ graph of the export model. 
GDP and population of the UK have a positive correlation with import level. But the population of EU has an inverse relation with the export level. Euro/Sterling rate has a negative correlation with the export level. But in the export model, the exchange rate may have a small effect because the invoicing currency in the EU is mainly in Euro.

Dependent Variable: LNUKIMEU

Method: Least Squares

Date: 09/21/18 Time: $20: 35$

Sample (adjusted): 19732017

Included observations: 45 after adjustments

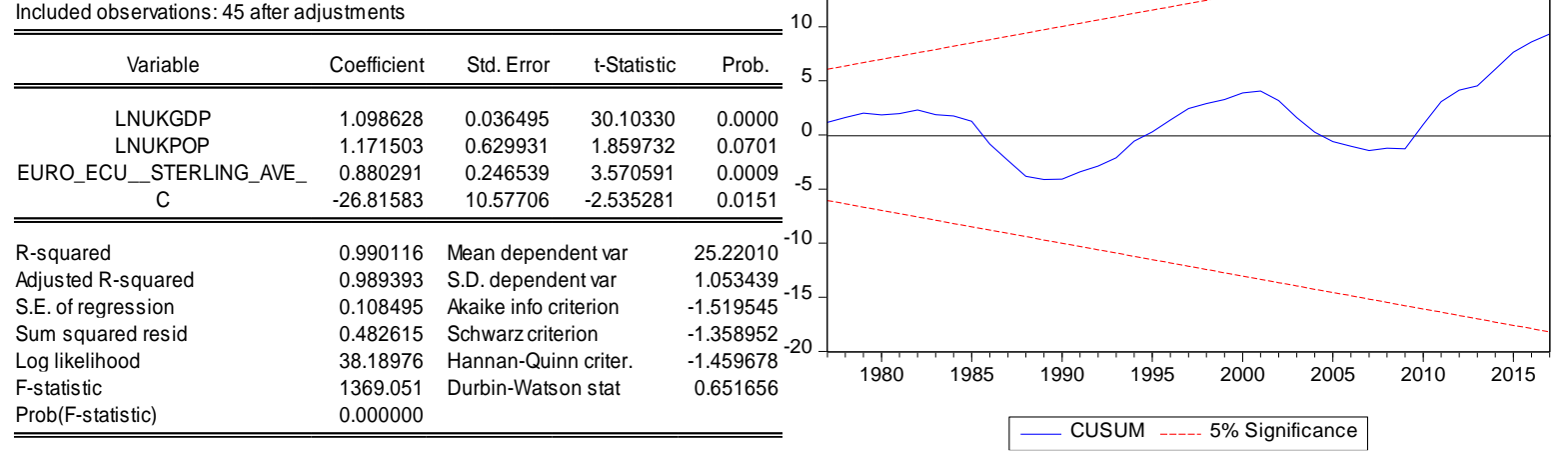

Dependent Variable: LNUKEXEU

Method: Least Squares

Date: 09/21/18 Time: $20: 40$

Sample (adjusted): 19732017

Included observations: 45 after adjustments

\begin{tabular}{|c|c|c|c|c|c|c|c|c|c|c|c|c|c|}
\hline & \\
\hline Variable & Coefficient & Std. Error & t-Statistic & Prob. & 0 & & & & & & & \multirow{5}{*}{  } & \\
\hline \multirow{4}{*}{$\begin{array}{c}\text { LNEUPOP } \\
\text { LNEUGDP } \\
\text { EURO_ECU_STERLING_AVE_ } \\
\text { C }\end{array}$} & -6.789162 & 2.773037 & -2.448277 & 0.0187 & \multirow{4}{*}{-10} & & & & & & & & \\
\hline & 1.675540 & 0.134323 & 12.47394 & 0.0000 & & & & & & & & & \\
\hline & -1.534613 & 0.355419 & -4.317761 & $0.0001^{-}$ & & & & & & & & & \\
\hline & 112.4677 & 51.71923 & 2.174582 & 0.0355 & & & & & & & & & \\
\hline \multirow{7}{*}{$\begin{array}{l}\text { R-squared } \\
\text { Adjusted R-squared } \\
\text { S.E. of regression } \\
\text { Sum squared resid } \\
\text { Log likelihood } \\
\text { F-statistic } \\
\text { Prob(F-statistic) }\end{array}$} & 0.977341 & \multicolumn{2}{|c|}{ Mean dependent var } & $25.28224-$ & -20 & & & & & & & & \\
\hline & 0.975682 & \multicolumn{2}{|c|}{ S.D. dependent var } & 0.944447 & & & & & & & & & \\
\hline & 0.147278 & \multicolumn{2}{|c|}{ Akaike info criterion } & -0.908306 & & & & & & & & & \\
\hline & 0.889320 & \multicolumn{2}{|c|}{ Schwarz criterion } & -0.747714 & -30 & & & & & & & & \\
\hline & 24.43688 & \multirow{2}{*}{\multicolumn{2}{|c|}{$\begin{array}{l}\text { Hannan-Quinn criter. } \\
\text { Durbin-Watson stat }\end{array}$}} & -0.848439 & & \multirow[t]{2}{*}{1980} & \multirow[t]{2}{*}{1985} & \multirow[t]{2}{*}{1990} & \multirow[t]{2}{*}{1995} & \multirow[t]{2}{*}{2000} & \multirow[t]{2}{*}{2005} & \multirow[t]{3}{*}{2010} & \multirow[t]{2}{*}{2015} \\
\hline & 589.4652 & & & 0.524036 & & & & & & & & & \\
\hline & 0.000000 & & & & & & & $-\mathrm{CU}$ & UM -... & $5 \%$ Sigr & cance & & \\
\hline
\end{tabular}

The import model is:

Inim $=-26.81+1.09$ Inukgdp +1.17 Inukpop +0.88 euro/sterling rate

Ceteris paribus, the $1 \%$ rise in the euro/sterling rate causes an increase of $0,88 \%$ Britain's import from the EU.

The export model is:

Inex $=112.46-6.78$ Ineupop +1.67 Ineugdp $-1.53 *$ Euro/sterling rate

Ceteris paribus, the $1 \%$ rise in the euro/sterling rate causes a decrease in Britain's export by $1,53 \%$.

Hypothesis of whether the exchange rate affects the trade level between the EU and the UK is not accepted. The rise in the exchange rate was expected to reduce imports from Europe, and increase exports, while different results were achieved. $\mathrm{H} 1$ is accepted. The effect of the exchange rate in the models was insignificant. Therefore, since the change in the exchange rates did not affect the UK's trade, the entry of Britain in the monetary union would not lead to significant changes. 


\section{FINDINGS AND DISCUSSIONS}

According to the Draft Withdrawal Agreement Brexit, a single customs territory between the Union and the United Kingdom shall be established ("the single customs territory") until the future relationship becomes applicable. Accordingly, Northern Ireland is in the same customs territory as Great Britain. (European Commission, 2018c: 310). Customs Union is the best option for the UK in that the UK will have closer trade relations with the EU and on the other side, will have its own foreign trade policy.

According to the European Parliament (European Commission, 2018c: 24), in the case of hard Brexit, UK would be responsible of its own trade policy in the WTO and this may reduce its bargaining position in the WTO rounds. However, the member countries in WTO form groups according to their interests and positions. The United Kingdom will probably on the developed countries side with the United States and the European Union and can defence its own proposals. So, this may not reduce its bargaining position in the WTO rounds.

\section{CONCLUSION}

The negotiations of Brexit came almost to an end. However, the future relationship is not precise yet. Two options were discussed: hard exit and soft exit. In the case of hard Brexit, the UK will be in the customs union. In contrast to hard Brexit, soft Brexit ensures the access to the single market. As immigration was one of the arguments in the exit campaigns, the single market option may not be acceptable by the United Kingdom. From the perspective of economic integration stages, the first best would be the Customs Union which foresees the free movement of goods. The UK would be responsible of its own trade policy against the other countries. If both sides do not agree on the Customs Union, then the second best will be free trade area, because the UK and the EU can make trade agreements that cover certain products which are traded mostly. For the other products, the UK can replace EU's imports by cheaper imports from third countries. The future UK-EU relationship will depend also on the UK's relations with the United States. As the United States is the most important trade partner of the UK, the EU-UK relations can move to a looser form of economic integration stage like free trade area in time, if US-UK trade relations deepen even more. This would show that de Gaulle was right in his concerns over UK's EU membership when he vetoed the UK's application because of the UK-US close trade relations. On the other hand, it is possible that the EU changes its trade policy towards the US in the future. So, the Customs Union which foresees closer relations than the free trade area is the best choice for the United Kingdom.

\section{REFERENCES}

Akses, S., Ataç, E., Ceran, A., Çapanoğlu, S., İleri, C., Kıvılcım, I., Şahin, Y. (2016). Britanya referandumu ve sonrasi: AB entegrasyon sürecinin geleceği ve Türkiye. İktisadi Kalkınma Vakfı (284). ISBN: 978-605-5984-77-9.

Baldwin, R., Wyplosz, C. (2006). The economics of European integration. Second Edition. New York, McGraw-Hill.

BBC. (2017, October 04). Edward Heath: A profile of the former UK prime minister. Retrieved from http://www.bbc.com/news/uk-politics33772016 .

Begg, I. (2016). Brexit: why, what next and how? CESifo Forum, 17 (1). pp. 30-36. ISSN 1615- 245X.

Bulmer, S., Quaglia, L. (2018). The politics and economies of Brexit. Journal of European Public Policy.25 (8): 1089-1098. DOI: 10.1080/13501763.2018.1467957.

Efe, H. (2017). Brexit sonrası Birleşik Krallık ve Avrupa Birliği arasindaki tek pazar üzerine müzakereler: "sert" Brexit mi, "yumuşak" Brexit mi? E. Erol \& D. Şekeroğlu (Ed.). In: BREXIT - Elveda Avrupa İngiltere'nin AB'den ayrilmasindan sonra Avrupa bütünleşmesi ve Türkiye-AB ilişkilerinde firsatlar ve tehditler (Siyasal Kitapevi, pp. 109-136). Ankara.

EFTA (n.d.). The basic features of the EEA agreement. Retrieved from http://www.efta.int/eea/eea-agreement/eea-basic-features.

European Central Bank (n.d.). Economic and monetary union. Retrieved from https://www.ecb.europa.eu/ecb/history/emu/html/index.en.html.

European Commission (2018a). Countries and regions. Retrieved from http://ec.europa.eu/trade/policy/countries-and-regions/.

European Commission (2018b). Intra and Extra-EU trade by member state and by product group. Retrieved from https://ec.europa.eu/eurostat/en/web/products-datasets/-/EXT_LT_INTRATRD.

European Commission (2018c). Draft withdrawal agreement, TF50 (2018) 55 - Commission to EU27. Retrieved from https://ec.europa.eu/commission/sites/beta-political/files/draft_withdrawal_agreement_0.pdf. 
European Parliament (2016, February 18). The UK 'rebate' on the EU budget: An explanation of the abatement and other correction mechanisms. Retrieved from http://www.europarl.europa.eu/thinktank/en/document.html?reference=EPRS_BRI\%282016\%29577973.

European Parliament (2015 March). A history of European monetary integration. Retrieved from http://www.europarl.europa.eu/RegData/etudes/BRIE/2015/551325/EPRS_BRI(2015)551325_EN.pdf.

European Union (2006, June 30). United Kingdom: EMU opt-out clause. Retrieved from http://publications.europa.eu/resource/cellar/b2878f0aec3b-451d-a90c-1345c0089462.0002.02/DOC_2.

European Union External Action (2016, September 26). Liechtenstein and the EU. Retrieved from https://eeas.europa.eu/headquarters/headquarters-homepage_en/7701/Liechtenstein\%20and\%20the\%20EU.

Hunt, A., Wheeler, B. (2018, January 27). Brexit: All you need to know about the UK leaving the EU. Retrieved from https://www.bbc.com/news/uk-politics-32810887.

Konuralp, E., Adaş, S. (2018). Ya Brexit sonrası? Birleşik Krallık'ın AB'den kopuş dönemeci ve alternatifleri. BEÜ SBE Derg.,7(2), 518-540.

Lisbon Treaty, Article 50 (n.d.). Retrieved from http://www.lisbon-treaty.org/wcm/the-lisbon-treaty/treaty-on-European-union-andcomments/title-6-final-provisions/137-article-50.html.

Lynch, M. (2015). Access to history, Britain 1945-2007. Second Edition. London, Hodder Education.

Office for National Statistics (2018, July 16). Trade in goods, country-by-commodity experimental data: 2011 to 2016. Retrieved from https://www.ons.gov.uk/economy/nationalaccounts/balanceofpayments/articles/tradeingoodscountrybycommodityexperimentaldata2011to20 16/2018-04-16.

Office for National Statistics (2018, July 16). International trade in services by partner country, UK: January to March 2018. Retrieved from https://www.ons.gov.uk/businessindustryandtrade/internationaltrade/bulletins/exportsandimportsstatisticsbycountryforuktradeinservices/jan uarytomarch2018.

Pettinger, T. (2016, July 6). UK exchange rate mechanism crisis 1992. Retrieved from https://econ.economicshelp.org/2008/12/exchange-ratemechanism-crisis-1992.html.

Redhill Academy (n.d.). Changes in the 6 economic https://www.theredhillacademy.org.uk/pluginfile.php?file=\%2F7036\%2Fmod_resource\%2Fcontent\%2F0\%2Fchanges_in_th_UK_economy.pdf.

Robson, P. (1998). Economics of international integration. Third Edition. New York: Routledge.

Sampson, T. (2017). Brexit: the economics of international disintegration. Journal of Economic Perspectives. 31(4): 163-184. doi=10.1257/jep.31.4.163.

Sims, A. (2016, October 03). What is the difference between hard and soft Brexit? Everything you need to know. Retrieved from http://www.independent.co.uk/news/uk/politics/brexit-hard-soft-what-is-the-difference-uk-eu-single-market-freedom-movement-theresamay-a7342591.html.

Soytürk, M. (2017). Büyük Britanya'nın Avrupa Birliği ile ilişkisi ve Brexit. The Journal of International Scientific Researches, 2 (4), 72-72. https://doi.org/10.23834/isrjournal.280527.

The Electoral Commission (n.d.). EU referendum results. Retrieved from https://www.electoralcommission.org.uk/find-information-bysubject/elections-and-referendums/past-elections-and-referendums/eu-referendum/electorate-and-count-information.

The Telegraph. (2016, June 16). Britain's 40-year relationship with the EU. Retrieved from https://www.telegraph.co.uk/politics/2016/06/16/britains-40-year-relationship-with-the-eu/.

Van Reenen, J. (2016). Brexit's long-run effects on the U.K. economy. Brookings Papers on Economic Activity, Massachusetts Institute of Technology. 367-383. 